Gerión. Revista de Historia Antigua

ISSN: 0213-0181

http://dx.doi.org/10.5209/GERI.59917

\title{
La Contestania ibérica frente a Cartago: fenómenos regionales y respuestas locales
}

\author{
Jorge García Cardiel ${ }^{1}$
}

Recibido: 21 de agosto de 2017 / Aceptado: 16 de octubre de 2017

Resumen. El presente artículo analiza la diversidad de respuestas que las distintas comunidades locales del sureste peninsular ofrecieron ante la presencia cartaginesa. Los contactos coloniales del siglo IV y primera mitad del III a.C. dieron lugar a fenómenos de hibridación cultural focalizados en el Campo de Elche y ciertos puertos mediterráneos. En cambio, la invasión cartaginesa del 237 a.C. provocó la aparición de protectorados, el auge militarista y un acusado y heterogéneo proceso de negociación cultural. Palabras clave: siglo III a.C; segunda Guerra Púnica; iberos; colonialismo; hibridación.

\section{[en] Iberian Contestania versus Carthage: Regional phenomena and local responses}

\begin{abstract}
This paper aims to discuss the varying responses that the various local communities in South-eastern Spain provided to Carthaginian presence. Colonial contacts between the $4^{\text {th }}$ and early $3^{\text {rd }}$ centuries BC led to phenomena of cultural hybridization, mainly in Campo de Elche and some of the Mediterranean ports. Carthaginian invasion, however, led to the emergence of new protectorates, rise of militarism and a rapid and heterogeneous process of cultural negotiation.
\end{abstract}

Keywords: $3^{\text {rd }}$ century BC; Second Punic War; Iberians; Colonialism; Hybridization.

Sumario: 1. Introducción. 2. ¿Cartagineses antes de los bárquidas? El sur peninsular y la Contestania. 3. El imperialismo bárquida en el Sureste peninsular. 5. Conclusiones. 6. Referencias bibliográficas.

Cómo citar: García Cardiel, J. (2017): La Contestania ibérica frente a Cartago: fenómenos regionales y respuestas locales, en Gerión 35(2), 401-425.

1 Universidad Autónoma de Madrid. Grupo Occidens.
E-mail: jorge.garciac@uam.es 


\section{Introducción}

Desde que Amílcar cruzó el Estrecho en 237 a.C. hasta que en 206 las últimas tropas cartaginesas abandonaron Cádiz empujadas por las legiones romanas, se sucedieron poco más de tres décadas de ocupación militar púnica de una parte de la Península Ibérica. Menos tiempo aún duró esta si atendemos únicamente al sureste peninsular, al área circunscrita entre Cartagena y la desembocadura del Júcar que los romanos denominarían más tarde Contestania, ${ }^{2}$ en la que las tropas bárquidas solo se hicieron presentes, que tengamos noticia, desde la fundación de Carthago Nova en 227 a.C. hasta la caída de la ciudad dieciocho años después. Dieciocho años tan solo, buena parte de ellos marcados por la guerra, y sin embargo los cartagineses imprimieron en las estructuras sociopolíticas y culturales locales una huella de tal calado que se ha llegado a afirmar, y posiblemente con razón, que los iberos entraron definitivamente en el mundo helenístico mediterráneo de la mano de los cartagineses, ${ }^{3}$ y que fueron estos últimos quienes dinamizaron el proceso urbano que más tarde Roma tan solo tendría que sistematizar en provecho propio. ${ }^{4}$ Entre cierto sector de la historiografía incluso se habló durante décadas de una fase "ibero-púnica" de la cultura material ibérica del sureste, fase que comprendería los dos últimos siglos del primer milenio a.C. ${ }^{5}$

Ahora bien, hemos de plantearnos cómo la presencia bárquida, tan puntual en el tiempo, pudo cosechar una influencia tan profunda sobre las estructuras locales ibéricas. Y así ha hecho la historiografía en más de una ocasión, aunque lo fragmentario de las fuentes, como veremos, unido al fuerte esencialismo que ha impregnado muchas de las aproximaciones al respecto (cuyo objetivo fundamental era determinar si un yacimiento en concreto era "ibero" o "púnico", "indígena" o "semita"), han determinado que los resultados de estas investigaciones sean hoy más limitados de lo que desearíamos. Así, a raíz de sus descubrimientos en la necrópolis de La Albufereta, J. Lafuente ${ }^{6}$ retomó las fuentes clásicas que años antes había empleado A. Schulten, y sobre las que enseguida volveremos, para argüir que la presencia cartaginesa en la región alicantina había comenzado bastante antes de lo que se pensaba, y había sido de mucho mayor calado. En una línea similar, F. Figueras ${ }^{7}$ planteó que tras la batalla de Alalía Cartago acometió la fundación de factorías en el sureste, tales como Libisosa, Alone, Baria o Abdera, que tras el tratado con Roma serían reocupadas por los griegos. S. Nordström, ${ }^{8}$ por su parte, defendió que Tossal de Manises, La Albufereta, La Alcudia y La Escuera eran yacimientos púnicos, y que las necrópolis de El Molar y Cabezo Lucero eran cementerios de mercenarios al servicio de Cartago. En fechas mucho más recientes diversos trabajos han partido de una presencia cartaginesa duradera en la costa alicantina como factor explicativo de distintos fenómenos, ${ }^{9}$ y ello pese a que los trabajos de E. Llobregat, ${ }^{10}$ revolucionarios en este como en tantos

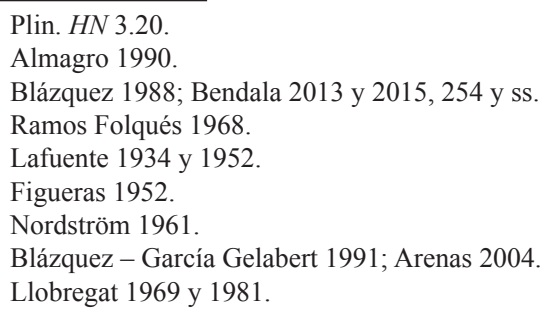


otros aspectos de la arqueología contestana, iniciaran el despegue de una postura autoctonista que rechazaba, con apenas excepciones, ${ }^{11}$ la posibilidad de la presencia cartaginesa en el sureste más allá de los años de dominación bárquida.

Intentando superar esta aproximación tradicional, bipolar, tendente a determinar si el Sureste peninsular estuvo o no gobernado por los cartagineses antes de la llegada de los bárquidas, en estas páginas trataré de aproximarme a una panorámica más completa (y compleja) de las relaciones que se establecieron entre foráneos y poblaciones locales, tanto durante la ocupación militar de finales del s. III a.C. como, en su caso, en los años anteriores, con objeto de comprender mejor la amplia gama de respuestas que las comunidades ibéricas propusieron ante la presencia del aparato imperialista cartaginés y durante la consiguiente Segunda Guerra Púnica.

\section{2. ¿Cartagineses antes de los bárquidas? El sur peninsular y la Contestania}

Gracias a los trabajos que recientemente E. Ferrer ${ }^{12}$ ha dedicado al tema, no creo necesario desgranar un recorrido historiográfico exhaustivo sobre la presencia cartaginesa en Iberia. No obstante, sí merece destacar, como ya hiciera el citado investigador, que la tesis de C. González Wagner, ${ }^{13}$ coincidente en el tiempo con el auge del autoctonismo en la arqueología española, dio por cerrada la polémica a la que antes aludía sobre una supuesta presencia cartaginesa en Iberia anterior al 237 a.C. Y sin embargo, y pese a la oposición tajante al respecto de todo un sector de la historiografía que se mantiene abiertamente escéptico, ${ }^{14}$ en los últimos años esta polémica ha vuelto a renacer, sustentada siempre sobre una serie de fragmentos dispersos entresacados de la literatura grecorromana, últimos vestigios de todo un corpus literario partidario de (o, simplemente, referido a) Cartago hoy desaparecido. ${ }^{15}$

El más conocido de estos fragmentos posiblemente sea el recuento del segundo tratado romano-cartaginés que nos ofrece Polibio, ${ }^{16}$ según el cual Cartago ve-

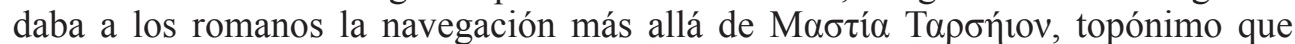
tradicionalmente se viene ubicando en Cartagena, que es considerada por tanto por parte de la historiografía como una "refundación" bárquida sobre un asentamiento cartaginés ya existente. ${ }^{17}$ Sin embargo, los estudios arqueológicos en el enclave, tanto bajo la ciudad moderna como en el fondo del puerto, apenas documentan vestigios de una posible ocupación anterior a la segunda mitad del s. III a.C. ${ }^{18}$ Por otra parte, el estudio detallado del topónimo que ofrece Polibio, de significado incierto (¿Mastia de Tartessos? ¿Mastia de los tartesios? ¿Mastia y Tartessos?), ${ }^{19}$ llevó a P. Moret $^{20}$ a ubicar la problemática Mastia fuera de la Península Ibérica, en África, cerca de la propia Cartago; hipótesis que ha sido refutada, a mi entender de manera suficientemente sólida, por E. Ferrer en una serie de trabajos en los que viene

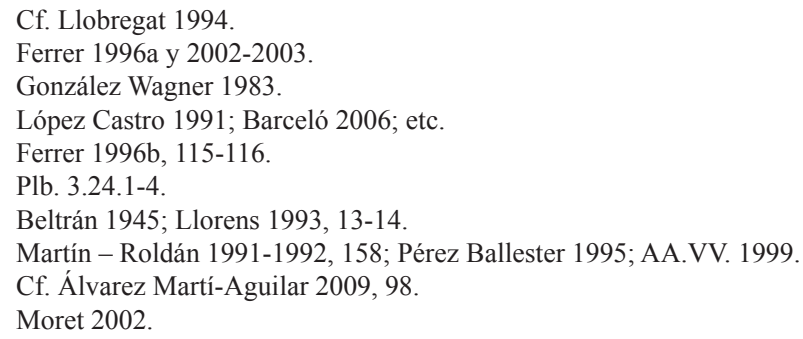


insistiendo en localizar Mastia en el sur peninsular, próxima al Estrecho de Gibraltar, ${ }^{21}$ donde por otra parte la referencia a Tartessos resultaría mejor comprensible, y donde se encontraría más en consonancia con la ubicación meridional de los mastienos según Hecateo ${ }^{22}$ y Herodoro. ${ }^{23}$ De aceptar esta última propuesta, que como veremos se encuentra en consonancia con los otros fragmentos a los que enseguida aludiré, observaríamos que a la altura de mediados del siglo IV a.C., Cartago mostraba una aspiración hegemónica sobre el sur peninsular, aunque el texto del tratado no nos detalla cómo cristalizaba dicha aspiración sobre el terreno.

El fragmento polibiano ha sido puesto en relación en ocasiones con otras dos noticias, que lamentablemente nos han llegado solamente a través de autores tardíos y para las que no se nos ofrecen cronologías explícitas, por lo que muchos autores han dudado incluso de su validez histórica, teniéndolas por recreaciones literarias. ${ }^{24}$ Es el caso del episodio que nos relata Justino en su epítome de Pompeyo Trogo, según el cual los gadiritas fundaron una ciudad en el sur peninsular pero tiempo después fueron atacados por sus vecinos, por lo que hubieron de ser socorridos por los cartagineses, quienes aprovecharon la oportunidad para asentarse en la región, ocurriendo todo ello tiempo antes de que Amílcar desembarcara. ${ }^{25}$ Nos encontraríamos, por tanto, ante una nueva referencia a la actividad imperialista ${ }^{26}$ cartaginesa pre-bárquida en el sur peninsular, ${ }^{27}$ si bien en este caso ya sí se nos habla explícitamente de una ocupación militar del territorio. En su reciente análisis de este fragmento, M. Álvare ${ }^{28}$ propuso que la ciudad atacada posiblemente no fuera Gadir, sino una "fundación gadirita", quizás Carteia, y que todo apuntaba a que el episodio reconstruido habría de localizarse a mediados del s. IV a.C.

Hacia las mismas fechas, por cierto, situó J. Alvar ${ }^{29}$ el ataque naval protagonizado por el rey ibero Theron que nos narra Macrobio, ${ }^{30}$ aunque en este caso sí que se nos especifica que la ciudad atacada fue Gadir, de modo que nos encontraríamos ante dos episodios violentos distintos, aunque derivados quizás de una misma fase de inestabilidad.

Puede que en este mismo contexto quepa ubicar también la noticia que transmite Vitrubio, ${ }^{31}$ tomándola de Ateneo el Táctico, sobre el origen del ariete, inventado según él en el contexto de un asedio cartaginés a la ciudad de Gadir. Es de señalar no obstante que M. Álvarez ${ }^{32}$ situó este episodio en el marco de la Segunda Guerra Púnica, concretamente durante la represión de la revuelta contra Cartago espoleada por los prefectos de las naves en 216 a.C., ${ }^{33}$ por lo que seguramente hablamos ya de un contexto histórico diferente al que ahora nos estamos refiriendo.

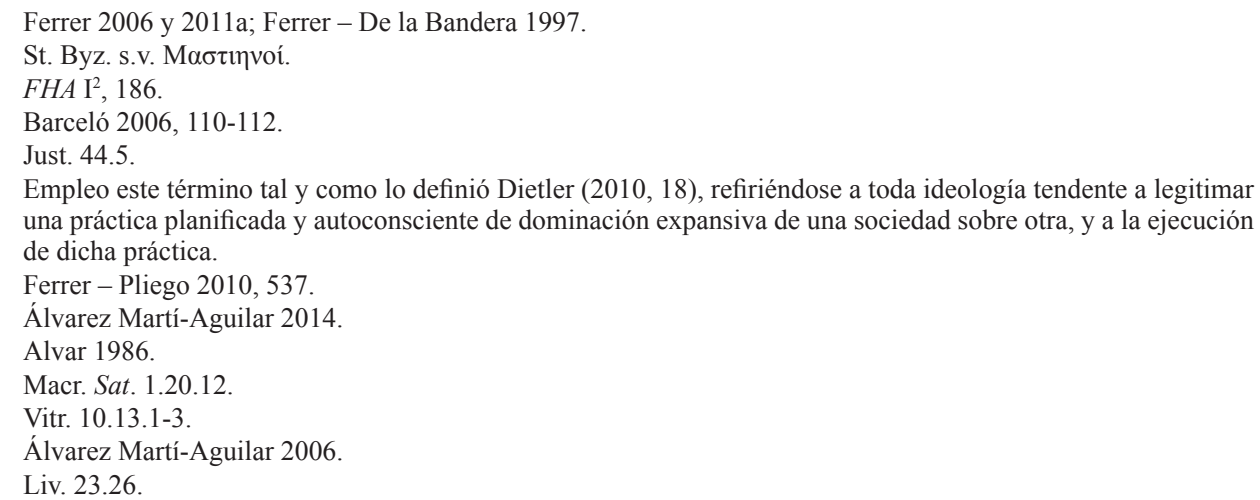


Algunas de estas noticias, en todo caso, podrían ponerse en consonancia con el comentario de Diodoro acerca de que las minas hispanas financiaban las campañas cartaginesas en Sicilia y Libia, ${ }^{34}$ o con la afirmación de Plinio de que el esparto comenzó a explotarse en Hispania con posterioridad a la primera incursión militar cartaginesa sobre estos territorios. ${ }^{35}$ Acerca de este último comentario, por cierto, $\mathrm{P}$. Barcelós $^{36}$ subraya que más adelante el propio Plinio aclarará que el esparto no fue empleado por los cartagineses hasta una época posterior a la de Teofrasto, ${ }^{37}$ por lo que Barceló entiende que esa "primera incursión militar cartaginesa" sería la de Amílcar. No obstante, creo que es de reseñar que Plinio tan solo deduce ("quo apparet") que el esparto comenzó a emplearse después de Teofrasto a partir del hecho de que el filósofo griego no se refiera a esta fibra en su obra, mientras que su afirmación acerca de que su empleo comenzó antes de la primera incursión militar en Hispania es mucho más tajante ("quidem"), y va acompañada de la precisión de que el esparto es varios siglos anterior al empleo del lino. Plinio se estaría refiriendo por tanto, pensamos, a una intervención anterior a la de Amílcar, algo que daría sentido a la precisión pliniana de que la invasión a la que él se refiere fue "la primera" ("ante Poenorum arma quae primun Hispaniae intulerunt").

Volviendo una vez más a Polibio, para terminar, reparemos, como ya otros autores hicieron, en que el megalopolitano afirmó que la intención de Amílcar al desembarcar en el sur peninsular era la de "recuperar" los intereses cartagineses perdidos en la región, ${ }^{38}$ y que, cuando párrafos antes enumeró los territorios sometidos a Cartago en vísperas de la Primera Guerra Púnica, aludió, llamativamente, a Iberia. ${ }^{39}$

En resumen, contamos con un puñado de vagas y heterogéneas menciones que, en conjunto, no obstante, podrían hacernos sospechar de una cierta presencia cartaginesa, y quizás incluso de un proyecto imperialista cartaginés en el sur peninsular desde al menos el s. IV a.C. Unas menciones que además no hacen sino corroborar lo que ya de por sí la arqueología venía sugiriendo en determinados enclaves de la región como Carteia, Villaricos o Tagilit, ${ }^{40}$ y que permiten explicar mejor los intercambios de población que desde estas fechas tan antiguas hubo entre la costa norteafricana y el sur peninsular. ${ }^{41}$ Unas menciones que, finalmente, ayudan a entender por qué Agripa afirmaba que la costa sur peninsular "originariamente era de los púnicos". ${ }^{42}$

Pero, en todo caso, repárese en que no he dejado de hablar hasta el momento del sur peninsular, y que con la más que dudosa excepción de Mastia Tarseion (probablemente no ubicada en Cartagena, como veíamos, sino en las cercanías del Estrecho), y quizás de la controvertida noticia pliniana sobre el esparto, no he hecho mención alguna a nuestra verdadera zona de interés en estas páginas, la Contestania. Espero que se me disculpe este largo excurso, pero el mismo tenía por objeto subrayar hasta qué punto, si bien las fuentes relativas a la presencia cartaginesa pre-bárquida en el sur peninsular son vagas y heterogéneas, el silencio deviene absoluto en lo relativo al sureste peninsular.

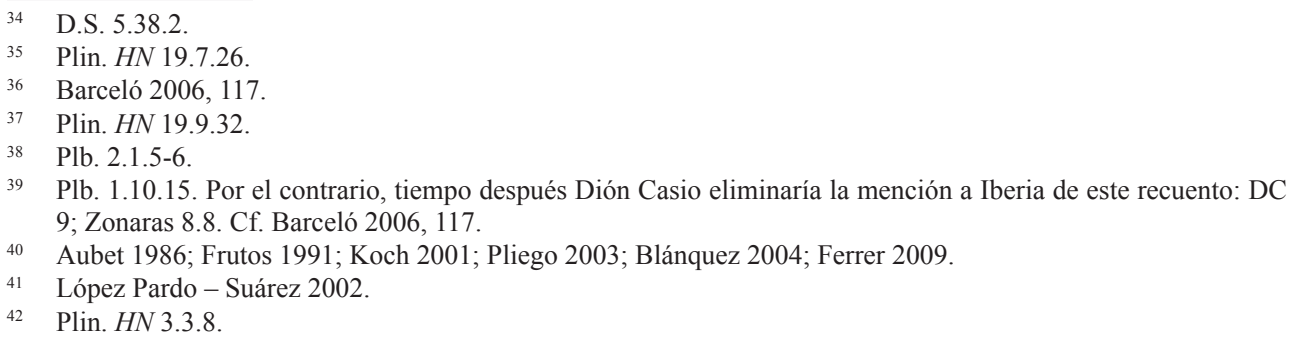


Revisemos, no obstante, qué sucede con el registro arqueológico. Y es que, aunque en la Contestania no se documentan asentamientos ni necrópolis propiamente cartagineses, como sí sucede en el sur peninsular, los contactos entre las diversas comunidades locales y los cartagineses hubieron de ir mucho más allá de un mero intercambio comercial continuado, ${ }^{43} \mathrm{y}$ en ocasiones parecen haber dejado una potente impronta en la esfera religiosa de dichas comunidades ${ }^{44}$ (Fig. 1).

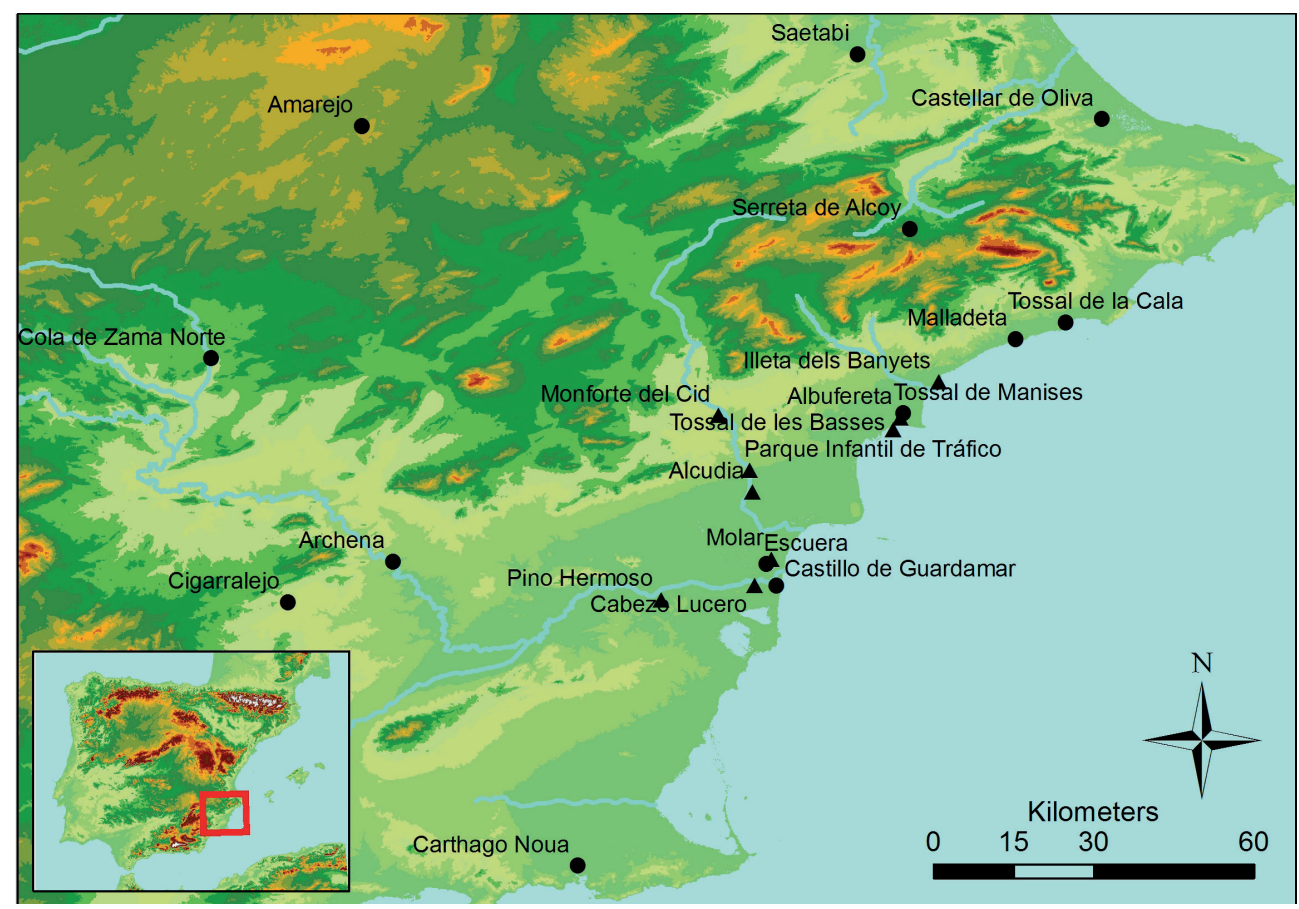

Figura 1. Principales yacimientos mencionados en el texto:

$\Delta$ : Anteriores a finales del siglo III a.C.

•: Relativos a finales del siglo III a.C.

Por ejemplo, en la Alcudia de Elche se levantó en el s. V a.C., según sus excavadores, un edificio de adobe de planta cuadrangular de $8 \mathrm{~m}$ de lado, diáfano y posiblemente descubierto, con una torre y un pequeño almacén adosados al exterior, y en cuyo interior se documentó una pequeña favissa repleta de material cerámico, en tanto que a su alrededor aparecieron diversos fragmentos escultóricos y un capitel protoeólico que posiblemente perteneciera a las columnas que flanqueaban la entrada; se trata, en definitiva, de un temenos al aire libre, cuya tipología encuentra sus paralelos más próximos en el mundo feniciopúnico, ${ }^{45}$ y cuya presencia es tanto más significativa cuanto que se trata, junto con las construcciones de la Illeta dels Banyets a las que en seguida me referiré, de los únicos ejemplos de templos propiamente dichos en el área ibérica, entendiendo por

\footnotetext{
Sala 2001-2002 y 2010; Aranegui 2010.

García Cardiel 2014a, 114-116, y 2016, 127-139.

45 Ramos Fernández 1995.
} 
"templos" edificios monumentales integrados en la trama urbana pero aislados del resto de construcciones.

A escasos kilómetros del templo ilicitano, en el Parque Infantil de Tráfico de Elche, nos encontramos con un nuevo recinto sacro que llama nuestra atención. Se trata de un espacio oval de unos $70 \mathrm{~m}^{2}$, compuesto por una plataforma de arcilla delimitada por una serie de piedras alineadas, la mayor parte de las cuales correspondían con fragmentos de antiguas esculturas y estructuras arquitectónicas. Una de estas esculturas, seguramente la más conocida, datada hacia el s. IV a.C. por paralelos estilísticos, representa una esfinge alada cabalgada por un jinete, ante la cual aparece una mujer que sostiene una flor de loto ante su pecho, y en torno a cuyo talle se pliegan dos grandes alas. ${ }^{46} \mathrm{Si}$ bien la representación de esfinges no es extraña a la plástica ibérica, su figuración como montura de seres humanos responde a ideas helenísticas, y nos retrotrae al llamado "Monumento de las Arpías" de Xanthos. ${ }^{47}$ Pero lo que más llama la atención es la figura femenina alada y con la flor de loto, sin duda una divinidad, que encuentra paralelos directos, casi idénticos, en el santuario ibicenco de Es Cuieram, consagrado a la diosa púnica Tanit ${ }^{48}$ (Fig. 2).

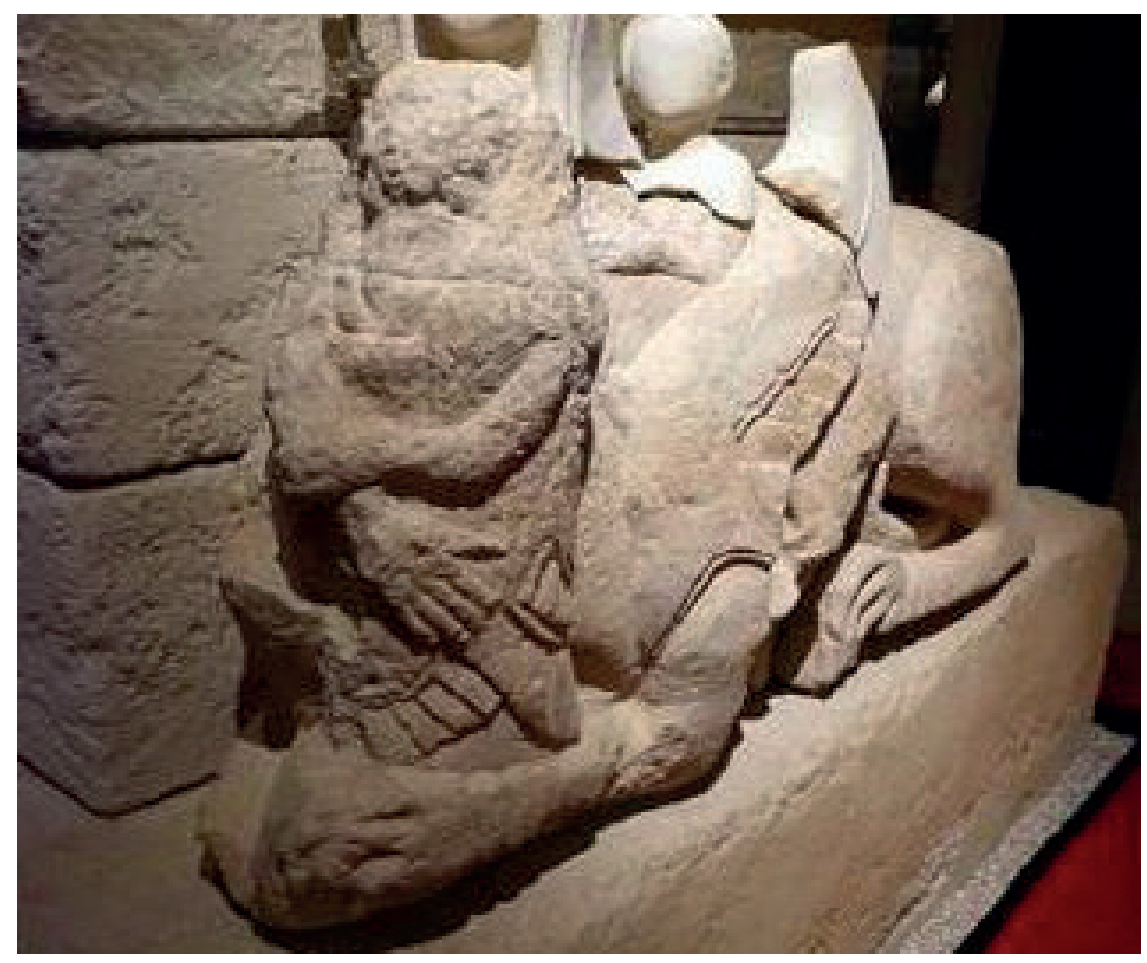

Figura 2. Divinidad femenina del Parque Infantil de Tráfico de Elche.

(Chapa - Belén 2011, 155)

\footnotetext{
46 Ramos Fernández - Ramos Molina 1992; Chapa - Belén 2011.

47 Demargne 1958.

48 Marín - Belén - Jiménez 2010.
} 
A no muchos kilómetros, en un arenero ribereño del Vinalopó situado en el término municipal de Monforte del Cid, se localizaron toda una serie de restos arquitectónicos y escultóricos, parte de los cuales aún se encuentran en proceso de estudio. Entre ellos, llamaré la atención sobre un pilar de sección rectangular rematado por una gola que, aunque en su momento fue fechado hacia el 500 a.C., ${ }^{49}$ recientemente se ha datado más bien en el s. IV a.C. ${ }^{50}$ Un cuidadoso examen del pilar demostró que, además de las falsas puertas que ornaban cada una de sus caras, con claros paralelos en los monumentos turriformes númidas, en una de estas caras se había grabado la representación en esbozo de un monumento turriforme, compuesto por podio, dos cuerpos cúbicos superpuestos rematados en sendas cornisas de gola, y una cubierta piramidal, en lo que podría considerarse el esquema canónico de este tipo de monumentos en el ámbito cartaginés. ${ }^{51}$

Pero volvamos a descender por el Campo de Elche, hasta cerca de la desembocadura del Segura, concretamente hasta la necrópolis de Cabezo Lucero, una de las más conocidas del mundo ibérico, con más de un centenar de sepulturas y una cronología que abarca todo el siglo V y los primeros tres cuartos del IV a.C. En la tumba 100, la llamada "Tumba del Orfebre", datada a mediados del s. IV a.C., junto a los restos del difunto se depositaron varios vasos griegos, una panoplia guerrera, una fíbula, dos fusayolas, unas pinzas de depilar, varias cuentas de collar y, llamativamente, un abundante lote de utilería de orfebre, incluyendo un nutrido grupo de matrices que muestran una iconografía sorprendentemente "orientalizante": combates entre héroes y grifos, representaciones de Bes, thymiateria, roleos, árboles de la vida, posibles bustos de Heracles... ${ }^{52}$ Unas imágenes que sin duda fueron cuidadosamente seleccionadas para formar parte del enterramiento del sujeto en cuestión; unas imágenes, en fin, sugerentemente distintas a la iconografía ibérica habitual de la época, pero que llaman la atención por su fuerte influencia punicizante.

En definitiva, nos encontramos ante un puñado de registros arqueológicos bastante próximos entre sí (todos ellos se sitúan en el Campo de Elche o en zonas limítrofes, siempre a menos de $20 \mathrm{~km}$ de la capital ilicitana), datables en el s. IV a.C. salvo el templo de la Alcudia, algo anterior, y que parecen mostrar en conjunto una honda influencia del imaginario púnico sobre las estructuras religiosas ibéricas, solo explicable mediante un contacto intenso y continuo entre las comunidades locales y las gentes de dicha procedencia cultural. En contra de lo que en ocasiones se ha sugerido,${ }^{53}$ creo que ninguna de estas imágenes basta por sí misma para identificar una comunidad de gentes púnicas habitando de forma permanente en el sureste peninsular, y mucho menos el dominio directo cartaginés de estos territorios, pero pienso que sí implican unos intercambios culturales bidireccionales y el surgimiento de realizaciones culturales, en este caso religiosas, híbridas, en las que se adoptó un lenguaje "punicizante" para expresar ideas que podrían ser aceptadas como propias por las diversas sociedades en contacto. No en vano, si los habitantes de la Alcudia sintieron la necesidad, inédita entre los iberos, de dotarse de un templo urbano, y si lo hicieron siguiendo modelos cuyos prototipos pueden rastrearse en el mundo púnico, no tenemos elementos suficientes como para dudar de que en

\footnotetext{
Almagro - Ramos 1986, 61.

Prados 2002-2003, 214.

Prados 2002-2003, 215.

Uroz 2006.

Cf. por ejemplo Poveda - Vázquez 2000.
} 
el interior de este templo se llevaran a cabo rituales propios de la religiosidad y de las deidades ibéricas, sino antes bien al contrario. Si bien la divinidad que guía a la esfinge del Parque Infantil de Tráfico se figuró con los atributos de la Tanit púnica, no deja de tratarse de una deidad femenina alada asociada a flores de loto y a tránsitos psicopompos como la que durante siglos presidiría, con toda probabilidad, el panteón ilicitano. Aunque la iconografía del monumento turriforme representado en el pilar de Monforte encuentra sus paralelos más directos en ambientes tunecinos, el propio concepto no sería ajeno al mundo ibérico, como el conjunto de Pozo Moro demuestra sobradamente. Y si la iconografía de las matrices de Cabezo Lucero resulta en conjunto llamativamente "orientalizante", sobre todo para su época, no deja de resultar cierto que ninguna de las imágenes representadas era estrictamente inédita en la plástica ibérica.

Es más, no solo nos encontramos con estas realizaciones híbridas prebárquidas en el entorno inmediato de la Alcudia de Elche, sino también en ciertos enclaves costeros puntuales para los que se conoce una fuerte pujanza comercial durante el Ibérico Pleno. Es el caso del poblado del Tossal de les Basses, en cuyas cercanías se sitúa la necrópolis de la Albufereta, una necrópolis ibérica datada entre los siglos IV y III a.C. en la que se observan tendencias algo anómalas en relación a los otros cementerios de la zona. ${ }^{54}$ Así, llama la atención la escasez de armas y fragmentos escultóricos amortizados en los enterramientos, así como la ausencia de encachados tumulares. Por el contrario, destaca la temprana y abundante aparición en el lugar de los pebeteros de terracota con forma de cabeza femenina (que en líneas generales no se distribuyen por el sureste peninsular, ni tan siquiera por Ibiza, hasta finales del s. III a.C.), y también la de un llamativo número de monedas púnicas en las tumbas, siempre una por sepultura, en un ritual inédito hasta la fecha en un mundo ibérico en el que no se concebía la economía monetaria, y que refuerza el carácter "punicizante" de la necrópolis. Asimismo resulta sobresaliente, por último, la abundancia de ungüentarios de filiación púnica (cuyo empleo en los rituales funerarios ibéricos no se generalizará hasta tiempo después) y de amuletos de pasta vítrea, huevos de avestruz, y figurillas diversas de terracota. Para los últimos momentos de la utilización de la necrópolis, incluso se habla de la posible existencia de un hipogeo de tipología púnica, aunque se trata de una noticia problemática referente a una excavación antigua y que en todo caso podría corresponder a una tumba de la última fase de la necrópolis, la relativa a la refundación bárquida del enclave, de la que enseguida hablaré.

Anomalías todas las cuales, por cierto, aparecen en la necrópolis aledaña a un asentamiento en el que se documentaron tres terracotas que representaban otros tantos birremes, posiblemente cartagineses a juzgar por su tipología. ${ }^{55}$

Finalmente, merece la pena destacar también el caso de otro puerto situado algunos kilómetros más al norte, el de la Illeta dels Banyets, ya mencionado. Se trata en realidad de una barriada industrial localizada sobre una pequeña península costera, destinada al procesamiento de productos pesqueros y a su posterior comercialización, y datada entre finales del s. V y mediados del III a.C. ${ }^{56}$ En ella, han aparecido hasta seis posibles lagares cuyas piletas estaban recubiertas de un fino mortero hidráulico

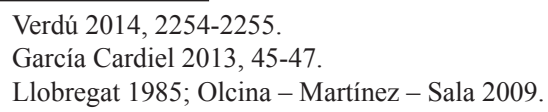


de base caliza, solo comparables en la Península con ciertas estructuras de Castillo de Doña Blanca (Cádiz); tampoco es habitual el volumen y la heterogeneidad de los materiales cerámicos áticos documentados, ni sobre todo la acumulación de grafitos ibéricos, grecoibéricos y púnicos atestados sobre ellos, en un volumen solo comparable al del pecio de El Sec, un barco cartaginés hundido en el segundo cuarto del s. IV a.C. en las costas de Mallorca. ${ }^{57}$ Pero sobre todo en la Illeta llaman la atención los dos templos que presiden el centro del poblado (máxime cuando, como señalaba antes, se trata de los dos únicos templos sensu stricto del mundo ibérico junto con el de la Alcudia): el templo A, un edificio con pronaos e interior tripartito de casi cien metros cuadrados, con una entrada flanqueada por columnas y en cuyo interior se halló un pebetero de terracota con forma de cabeza femenina; y el templo $\mathrm{B}$, un recinto cuadrangular y diáfano de unos cincuenta metros cuadrados para el que se han propuesto dos fases de uso, una primera en la que el espacio estaría presidido por una massebah, y una segunda en la que lo que destacaría sería una columna exenta de madera, a la manera de las asserah feniciopúnicas. ${ }^{58}$

Resumiendo, frente al silencio absoluto de los textos, el registro arqueológico nos ofrece en la Contestania vestigios del surgimiento de realidades culturales híbridas propias de un espacio colonial, que responden en general a estrategias políticas locales de mimetismo, ${ }^{59}$ por las que los "colonizados" adoptarían ciertos rasgos culturales exógenos para tratar de situarse en una mejor posición de negociación en el encuentro colonial, tanto frente a los "colonizadores" como en lo que respecta a la política interna de las propias comunidades locales. Unos "colonizadores", púnicos en este caso, cuya presencia regular y sistemática y cuya cercanía respecto de las comunidades locales viene avalada por estas realizaciones culturales, pero que no implica forzosamente su residencia física y perdurable en la región. Hablo, por ende, de "hegemonía", de control de ciertos resortes comerciales si se quiere, valiéndose de la proximidad del puerto púnico de Ebussus y de las interferencias que en los intercambios locales y comarcales provocaría la piratería, un fenómeno contra el que solo una potencia como Cartago podría luchar con garantías; ${ }^{60}$ pero no me refiero a un proyecto imperialista como el que, tal y como hemos visto, podría colegirse para el sur peninsular según las fuentes literarias. Y hablo de unas estrategias de mimetismo cultural que, qué duda cabe, se verían facilitadas por la vieja convivencia y progresiva hibridación entre las comunidades locales del sureste y las gentes fenicias que se habían asentado en la zona medio milenio atrás. ${ }^{61}$

\section{El imperialismo bárquida en el Sureste peninsular}

La situación descrita para la Contestania, no obstante, cambió radicalmente durante la segunda mitad del s. III a.C. Como es bien sabido, en el 237 a.C. Amílcar desembarcó en la Península Ibérica y se impuso como primer objetivo el control de las minas de Sierra Morena, cuya producción debía favorecer la recuperación de Cartago después de la Primera Guerra Púnica. Solo en un segundo momento, tras el fallecimiento

\footnotetext{
Arribas et alii 1987.

Sala 2001-2002, 296-297; García Cardiel 2014b, 82-84.

Bhabha 1994, 86.

Álvarez-Ossorio - Ferrer - García Vargas (coords.) 2014.

González Prats 2010; García Menárguez - Prados 2017.
} 
de Amílcar y una vez que Asdrúbal consiguió consolidar su dominio sobre la Alta Andalucía, la atención cartaginesa se desplazó hacia el sureste peninsular, cuyo control permitiría encaminar hacia Cartago la producción metalífera andaluza de manera mucho más segura y eficaz que a través de Gadir y el Estrecho de Gibraltar. Con este objetivo, Asdrúbal no dudó en fundar la que sería la capital púnica de los territorios hispanos, Carthago Nova, en el mejor puerto natural de la región y junto a otras importantes minas. ${ }^{62}$

De hecho, ya antes de la fundación cartagenera Amílcar había fundado un primer

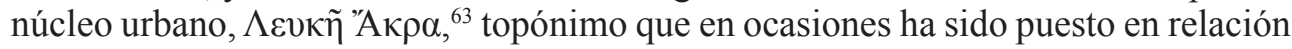
con la actual Alicante debido a la proximidad que Diodoro le supone respecto de la ciudad indígena sitiada por los cartagineses llamada ${ }^{~} E \lambda \iota \kappa \tilde{\eta}$, a su vez identificada por los historiadores modernos con Elche por criterios fonéticos. Ahora bien, es esta una doble identificación basada en argumentos un tanto endebles y que no se corresponde bien con el desarrollo de los acontecimientos tal y como los plantea Diodoro, según el cual los cartagineses primero sometieron por completo a los oretanos antes de dirigirse hacia el sureste y fundar Carthago Nova, ciudad que el siciliano aclara que se encontraba "ya junto al mar"; todo ello hace pensar que Akra Leuké, como la misma Heliké, se ubicaban aún en la Alta Andalucía, y no en la costa alicantina. ${ }^{64}$

En todo caso, la fundación de Carthago Nova, la de Akra Leuké y la de una tercera ciudad de la que Diodoro no nos proporciona el nombre, ${ }^{65}$ evidencian la puesta en práctica por parte de Asdrúbal de todo un programa de vertebración territorial basado en la creación sistemática de una red de puntos fuertes, de carácter urbano, desde los que asegurar el control de las vías de comunicación. Aun sin tratarse de ciudades helenísticas propiamente dichas, al estilo de las creadas por los reinos helenístico del Mediterráneo Oriental, ${ }^{66}$ sí puede considerarse que un proyecto territorial como este, implantado a gran escala sobre un mosaico de entidades políticas relativamente autónomas sobre las que se pretendía ejercer una política colonial imperialista, responde a una concepción helenística del poder. ${ }^{67}$ Una concepción que entrañaba la consideración del gobernante como constructor de ciudades y difusor de la civilización helenística, jefe militar carismático y protegido de la divinidad. ${ }^{68}$

Una concepción que, de hecho, quedó plasmada a la perfección en el paisaje contestano. La capital púnica en Iberia, Carthago Nova, sería desde su misma fundación el mayor núcleo urbano, con diferencia, del sureste peninsular ${ }^{69}$ y sus formidables murallas, ${ }^{70}$ que introducían en la región rudimentos poliorcéticos desconocidos hasta entonces como la estructura de casamatas o los basamentos de sillares almohadillados, unidas al gran palacio que Asdrúbal se hizo construir en la parte alta de la ciudad en conexión con diversos espacios sacros consagrados a las divinidades cívicas ${ }^{71}$ explicarían el epíteto que Livio dedicaría a la ciudad,

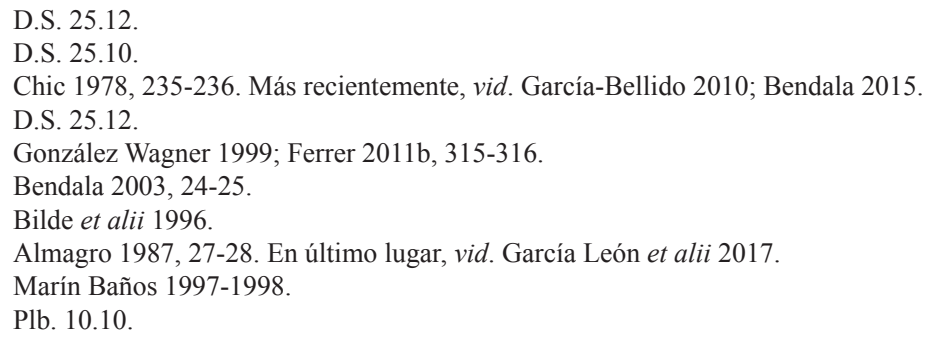


urbs opulentissima omnium in Hispania, ${ }^{72}$ y que en cierta manera nos podría dar una idea del efecto que la ciudad produciría en el imaginario y la percepción de las comunidades locales de la región.

Pero siguiendo la costa, más al norte, nos encontramos con una nueva fundación bárquida próxima a la actual ciudad de Alicante y junto al ya citado Tossal de les Basses. En efecto, parece que en la segunda mitad del siglo III a.C. el mencionado poblado ibérico se abandonó y que al otro lado de la Albufereta, en la cima del Tossal de Manises, se promovió un ambicioso proyecto constructivo que incluía la urbanización de un área de 2,5 ha protegida por una muralla antecedida de antemural y erizada de torres dotadas de maquinaria de asedio. La complejidad de estas construcciones y su cronología hubieran dado ya pie para interpretar este nuevo enclave como un fuerte púnico al norte de Carthago Nova que protegería la vía de comunicación que, a través de los valles alcoyanos, conectaba el sureste peninsular con la costa levantina; pero la aparición de cisternas a bagnarola horadadas al pie de las torres para su abastecimiento de agua, y de decenas de proyectiles de artillería junto a estas cuyo análisis petrográfico indica que fueron fabricados en las proximidades de Cartagena, aclaran aún más la cuestión. ${ }^{73}$ No sabemos si el Tossal de Manises sería, como en ocasiones se ha discutido, Akra Leuké o la "tercera ciudad" de la que hablaba Diodoro, pero sí parece claro que formaría parte del esquema imperialista bárquida para el control del territorio (Fig. 3).

Respecto a la citada consideración helenística de los gobernantes púnicos, merece la pena recordar también que Aníbal, antes de comenzar su campaña ultrapirenaica, peregrinó al templo de Melqart en Gadir buscando la sanción divina para su campaña, ${ }^{74}$ y que en las monedas emitidas por la dinastía bárquida los anversos mostraban la efigie del dios. Tampoco olvidemos el reverso de estas mismas acuñaciones, donde aparecen con frecuencia elefantes de guerra o trirremes, reflejando así el otro gran ámbito de representación del poder helenístico, el control de la violencia. ${ }^{75} \mathrm{Ni}$ perdamos de vista la enorme significación que las acuñaciones mismas hubieron de tener como mecanismo ideológico entre una población local que hasta el momento no había empleado una economía monetaria, pero cuyos guerreros alistados en los ejércitos anibálicos recibirían sus soldadas en estas monedas. Unos mercenarios que, por cierto, proclamaron $d u x$ (con todas las implicaciones religiosas y militares que dicho concepto comportaba en la Antigüedad) a su general Aníbal al comienzo de la guerra. ${ }^{76}$

Desde estas bases ideológicas, Cartago pugnó por el control de amplias zonas del territorio ibérico, parte de cuyo excedente trataría de fiscalizar en beneficio propio. Para ello, los generales bárquidas hubieron de sostener feroces combates contra las comunidades locales, fundamentalmente en la Alta Andalucía, la Meseta y en torno a la ciudad de Sagunto, enfrentamientos que la política cartaginesa supo combinar con pactos, alianzas y promesas contraídas con las diversas aristocracias locales, pero también con el ejercicio continuo de la coacción, implícita o explícita. No en vano las fuentes literarias nos informan de que tanto Asdrúbal como Aníbal casaron

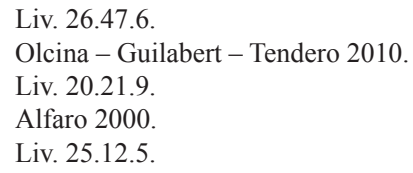


con sendas hijas de gobernantes ibéricos, ${ }^{77}$ pero también de que, antes de la guerra contra Roma, Aníbal decidió enviar a un gran número de guerreros ibéricos a Africa, evitando así que ni ellos ni sus comunidades causaran problemas en la retaguardia; $;^{78}$ idéntica razón por la que, cuando Escipión tomó Carthago Nova en 209 a.C., encontró en su interior una multitud de rehenes, más de trescientos según Polibio, tomados de las diversas aristocracias locales ibéricas, de cuya lealtad habrían de responder con sus vidas ante el poder cartaginés. ${ }^{79}$

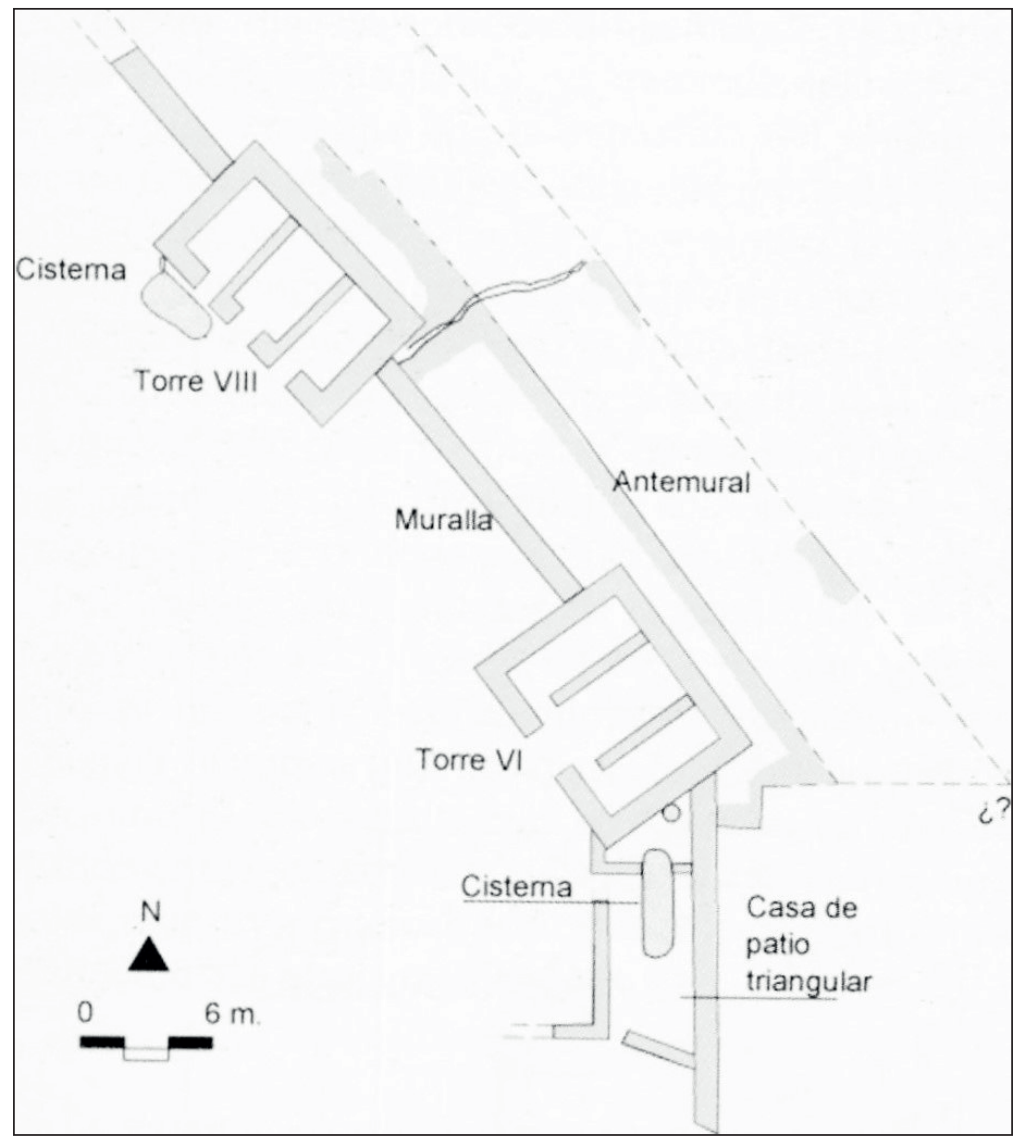

Figura 3. Tramo 5 de la muralla púnica de Tossal de Manises (Olcina 2005, 160).

Cartago se arrogaba así, aunando la ideología y la coacción más descarnada, un papel hegemónico sobre el sureste ibérico; papel hegemónico que las comunidades ibéricas habrían de reconocer, aunque cada una de ellas lo hiciera, como vamos a ver, desde diversos presupuestos. 


\section{Respuestas locales heterogéneas ante la hegemonía bárquida}

En efecto, puede considerarse que el establecimiento de la red de puntos fuertes en tiempos de Asdrúbal, con Carthago Nova a la cabeza, supuso la consolidación de la hegemonía cartaginesa sobre el territorio ibérico. Si bien no puede decirse que Cartago se hubiera anexionado de forma efectiva toda Iberia, sí constituía la fuerza militar más poderosa en la región, controlaba las principales vías de comunicación y algunos de los resortes económicos de primer orden y, a través de toda una serie de alianzas, pactos y golpes militares, había conseguido el vasallaje o la rendición del mosaico de unidades políticas locales que componían el mundo ibérico. La plasmación más evidente de todo ello fue la reunión de aristócratas ibéricos en Carthago Nova poco después de su fundación, con objeto de proclamar a Asdrúbal

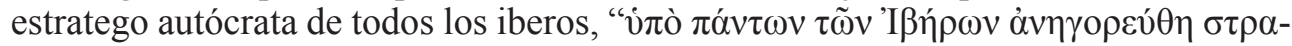

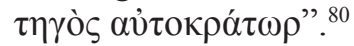

Ahora bien, como ya señalara L. Pérez Vilatela, ${ }^{81}$ Cartago nunca trató de manera homogénea a todas las entidades políticas existentes en la Península. Pero tampoco, añadiría yo, las diversas comunidades locales respondieron de igual manera ante el desafío púnico, sino que la presencia cartaginesa desató un nuevo proceso de negociación (política, económica, identitaria) que daría lugar a una amplísima casuística.

En lo referido al sureste peninsular, un caso particular en este sentido será el de la Serreta. Hasta la segunda mitad del s. III a.C., la Serreta había sido uno más del puñado de poblados en altura que habían coexistido en los valles alcoyanos, repartiéndose el control sobre la comarca sin que ninguno de ellos lograra imponerse sobre los demás. Pero a mediados del s. III a.C., la Serreta se hizo con el control total de los valles, en tanto que los otros asentamientos en altura fueron abandonados o quedaron subordinados a ella. En torno al núcleo urbano originario de la Serreta surgieron nuevos barrios que la convirtieron en uno de los mayores asentamientos del sureste, solo por detrás de Carthago Nova y a la par de la Alcudia de Elche, y el poblado entero se rodeó de una potente muralla que cerró el ya de por sí intrincado acceso al caserío y separó este del santuario situado en la cima del cerro; un poblado en torno al que además surgió un estilo decorativo vascular propio, y en el que se documenta el mayor conjunto de inscripciones ibéricas conocido, el mayor volumen de ponderales de época ibérica del que tengamos noticia, y el mayor lote de cerámica importada de todos los valles alcoyanos. ${ }^{82}$

Toda esta pujanza sólo puede entenderse como consecuencia de los desarrollos socioeconómicos y políticos internos del asentamiento ${ }^{83}$ pero, como ya hace años apuntaron algunos autores ${ }^{84}$ seguramente haya de ponerse en relación también con el contexto histórico en el que se produce dicho despegue. Pues no en vano este último vino acompañado del establecimiento de un flujo comercial bidireccional intenso entre la Serreta, que dominaba el acceso de los valles alcoyanos ( $y$, a través de él, el camino que llevaba desde el sureste hacia la costa levantina y el noreste; hacia Sagunto, por ejemplo), y el Tossal de Manises púnico, ubicado al comienzo de dicho camino y en la salida al mar más directa desde los valles. La Serreta se

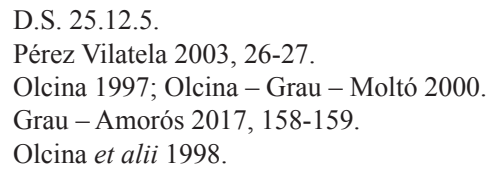


llenó en aquellos años de ánforas púnico-ebusitanas, de cerámicas campanienses y calenas, de morteros de pasta clara y de lucernas de procedencia centromediterránea o africana, e incluso las pocas monedas que se detectan en el asentamiento en esta época son todas ellas cartaginesas.

Es más, la influencia púnica se vislumbra igualmente en el santuario alcoyano: en él comenzó a practicarse el ritual ibérico más tradicional, la ofrenda de exvotos que representaban a los propios depositarios, pero estos exvotos no se fabricaron en piedra o en bronce como en los otros santuarios del momento, sino en terracota, un material que se generalizaría solo a partir de entonces en el mundo ibérico del sureste pero cuyo origen parece rastrearse en el universo cultural púnico; no en vano, de hecho, los mejores paralelos que se pueden señalar para los exvotos alcoyanos proceden precisamente de dicho ámbito cultural. ${ }^{85}$

En definitiva, todo apunta a que nos encontramos con una entidad política ibérica que, durante la segunda mitad del s. III a.C., estableció toda una serie de vínculos comerciales (y sin duda también políticos) con el poder hegemónico cartaginés, vínculos que los gobernantes del lugar justificaron ideológicamente a través de la hibridación de los ritos locales, y vínculos que permitirían a la Serreta desarrollarse y expandirse hasta convertirse en un verdadero protoestado. Desde luego, se trataría de unos vínculos que beneficiaron a ambas partes (los cartagineses se aseguraban la vía de comunicación que atravesaba los valles alcoyanos, y los gobernantes de la Serreta conseguían un socio comercial costero y se ganaban el amparo de la potencia militar hegemónica en la región), pero sin duda también unos vínculos desiguales, que consolidarían la red territorial cartaginesa con el establecimiento sobre los valles alcoyanos de un verdadero protectorado.

Un fenómeno que, de hecho, posiblemente no fuera único en el sureste peninsular, aunque por el momento sea el que mejor tenemos documentado. Por ejemplo, sabemos que durante la ocupación bárquida comenzó a acuñar moneda la primera ceca contestana, Saetabi, y que lo hizo consignando el nombre del lugar en ibérico y en púnico ${ }^{86} \mathrm{Y}$ desde luego un caso similar podría ser el de la Alcudia de Elche. Bien es cierto que resulta difícil aseverar si este poblado aumentó o no su tamaño durante la fase de dominio cartaginés (pues parece que los materiales de los estratos $\mathrm{E}$ y $\mathrm{F}$ se distribuyen por las 6 ha del poblado sin distinción alguna, aunque en realidad no se documenten estructuras arquitectónicas de ninguna de estas épocas), ${ }^{87}$ y la fuerte urbanización de la zona, unida a un menor esfuerzo prospectivo, determinan que nuestro grado de comprensión de las dinámicas poblacionales de la comarca sea menor que en lo referido a los valles alcoyanos. ${ }^{88}$ Pese a todo, parece claro que se trataba del mayor asentamiento de la comarca ya durante el Ibérico Pleno, y que en su interior habitaba una elite gobernante capaz de promover complejos programas escultóricos y una pujante arquitectura monumental. Apuntaba además en el apartado anterior que la Alcudia parece ser el centro de todo un influjo iconográfico "punicizante" activo ya desde el s. IV a.C., lo que nos habla de unos contactos privilegiados con los agentes coloniales cartagineses desde fechas anteriores a la conquista bárquida. Pero sucede que a partir de finales del s. III a.C. o comienzos del II a.C. la influencia de la

\footnotetext{
García Cardiel 2014a, 125-126, y 2014b, 84-86.

Beltrán 1961-1962.

Moratalla 2004-2005.

Moratalla 2005.
} 
Alcudia sobre su entorno parece crecer progresivamente, imponiendo sus programas iconográficos y sus acuñaciones sobre toda la parte meridional de la Contestania, proceso que culminará con la promoción colonial del enclave a mediados del s. I a.C. Con los datos disponibles, resulta difícil establecer si este despegue de la pujanza ilicitana se produjo bajo la égida romana, como generalmente se presupone, o ya algunos años antes, como resultado de la colaboración con el aparato imperialista bárquida. Ahora bien, creo que el enorme influjo punicizante que caracterizará la iconografía ilicitana durante su etapa de auge o la aparición de varios hipogeos de tipología púnica en las proximidades de la ciudad ${ }^{89}$ son datos reveladores que cuando menos hemos de considerar a este respecto.

En las proximidades de la Alcudia, en todo caso, encontramos algunos ejemplos que nos hablan de una hibridación cultural profunda, posiblemente fomentada por los gobernantes locales. Seguramente es el caso, por ejemplo, del sillar de Pino Hermoso, un bloque de arenisca con mortajas de grapas (esto es, el bloque formaría parte de un monumento mayor) que apareció en el transcurso de las labores agrícolas. En una de sus caras se representaba un caballo alado y un personaje antropomorfo alado, separados ambos por un elemento vertical que podría identificarse como un tronco de árbol o de palmera. En un principio la pieza fue datada por paralelos estilísticos a mediados del siglo III a.C., ${ }^{90}$ pero en realidad hoy día se considera que todos los paralelos aducidos, tal y como señala F. Prados, ${ }^{91}$ apuntan a la época bárquida, por lo que probablemente debamos igualmente situar este sillar en el contexto mencionado. Un contexto en el que se estaría representando el clásico tránsito psicopompo ibérico con un lenguaje punicizante. ${ }^{92}$

Otra posible evidencia de estos fenómenos podría ser el templo de la Escuera, levantado en un barrio periférico de este núcleo cercano a Elche en la segunda mitad del siglo III a.C., ${ }^{93}$ esto es, en la última fase de un poblado que había sido fundado unos dos siglos atrás y que sería abandonado a resultas de la Segunda Guerra Púnica. Hablo de un edificio singular de planta compleja, con patios y estancias con columnas exentas, en cuyo interior se acumulan las importaciones mediterráneas, la cerámica ibérica decorada e incluso un tesorillo de moneda cartaginesa. Este templo se ha comparado con el santuario de Kerkouan y otras áreas sacras púnicas del período, ${ }^{94}$ pero encuentra paralelos mucho más próximos en Torreparedones, Sant Miquel de Llíria y, sobre todo, Cigarralejo, ${ }^{95}$ edificio este último, el del Cigarralejo, que por cierto parece erigirse precisamente en el siglo III a.C. ${ }^{96}$

Ahora bien, a diferencia de lo que veíamos que ocurría en la etapa anterior, en época bárquida podemos observar cómo los influjos culturales púnicos calan profundamente en determinados aspectos de los imaginarios locales de buena parte del sureste ibérico, mucho más allá del entorno ilicitano. Así, a lo largo de la costa alicantina nos encontramos con toda una serie de espacios sacros que parecen surgir precisamente en esta época, ubicados en cerros costeros, y a los cuales los habitantes

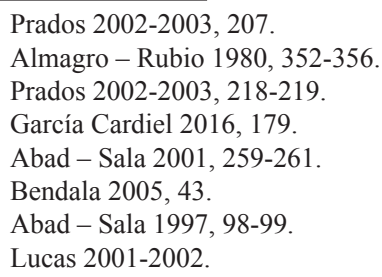


de los poblados cercanos ascenderían en peregrinación en determinadas festividades anuales para celebrar comidas rituales y depositar allí pebeteros de terracota con forma de cabeza femenina de estilo "Guardamar", en un tipo de ritual comunitario híbrido que se ha analizado en otro lugar y que muestra una fuerte componente "punicizante". ${ }^{97}$ Santuarios como estos serían los de Castillo de Guardamar, Malladeta o Tossal de la Cala.

Penetrando ya en el sureste meseteño, comprobamos que en la necrópolis de Cola de Zama Norte se documenta una tinaja de borde exvasado, que hemos datado a finales del s. III a.C. por paralelos con las cerámicas alcoyanas, y en cuyo costado se representa un carnassier ante una palmera. ${ }^{98}$ Elemento vegetal este último poco habitual en la iconografía ibérica, pero que puede ser puesto en relación con el típico icono de las monedas púnicas de caballo y palmera, o incluso también, como se propuso hace unos pocos años, con aquellas otras en las que se sustituye el caballo precisamente por un león (Fig. 4).$^{99}$

De hecho, internándonos aún más en la Meseta, en el asentamiento ibérico de El Amarejo, habitado desde al menos comienzos del s. IV a.C., documentamos a finales del s. III a.C. una práctica ritual novedosa, la amortización en un gran depósito votivo, conformado de una sola vez, de abundantes cerámicas, restos faunísticos, objetos de adorno y elementos relacionados con la actividad textil, artefactos que previamente se habrían sometido al fuego de las piras encendidas en el propio hoyo $\mathrm{o}$ en sus inmediaciones. ${ }^{100}$ Objetos entre los cuales, precisamente, encontramos una placa de cinturón de hierro recubierta de plata y remachada en bronce decorada con un guerrero que lleva las riendas de un caballo, tras el que se vislumbra una palmera; imagen que en mi opinión está reinterpretando nuevamente el mencionado esquema iconográfico cartaginés, delatando, como en el caso de Cola de Zama Norte, la influencia que los discursos ideológicos púnicos proyectaban hacia estas comarcas del interior, y la manera en la que los gobernantes locales capitalizaron esos discursos para subrayar su autoridad sobre sus respectivas comunidades en momentos tan convulsos como los de la época.

$\mathrm{Y}$ es que, para terminar, si algo caracterizó el último tercio del s. III a.C. en el sureste peninsular fue, seguramente, la inestabilidad. Independientemente del lugar en el que cada comunidad local consiguiera situarse en el cambiante equilibrio de poderes, e independientemente de las relaciones que cada grupo estableciera con la potencia hegemónica cartaginesa, la presencia de esta última en el sureste peninsular supuso en todo caso una profunda ruptura en las estructuras sociopolíticas ibéricas, que hasta ese momento nunca se habían visto expuestas directamente a una estructura estatal tan compleja, ni a ejércitos con semejante capacidad de acción y maniobra. La guerra compleja aparecía en la Península Ibérica, y su llegada marcaría el devenir político del sureste durante las siguientes décadas, primero en relación con la ocupación bárquida y más tarde con la Segunda Guerra Púnica, sin olvidar todas las tensiones y enfrentamientos entre comunidades ibéricas que ambos episodios traerían aparejados. Una situación que, en unos pocos años, motivaría cambios fundamentales en las estructuras políticas e ideológicas locales.

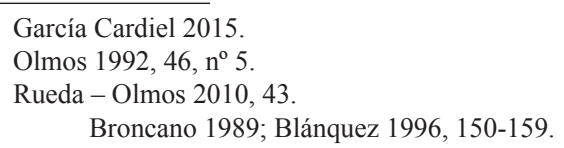




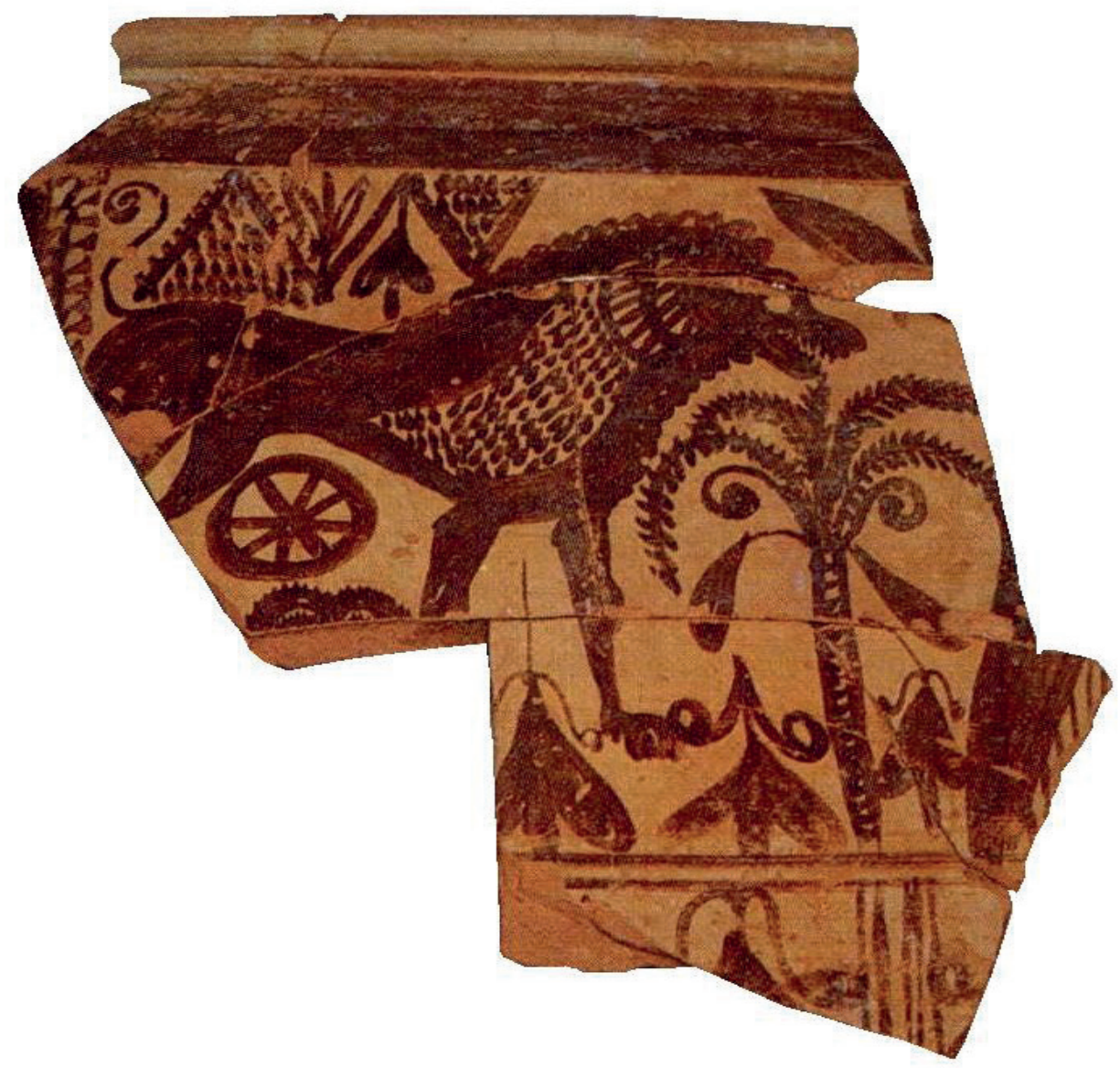

Figura 4. Vaso de Cola de Zama Norte (Olmos, dir., 1992, 46).

Así, si en la Época Plena ibérica las aristocracias locales del sureste peninsular habían tendido a subrayar su distinción mediante otros atributos, tales como la posesión de caballos, la ostentación de ricas vestimentas "civiles" o la relación con los dioses, a finales del s. III a.C. los gobernantes recuperaron el énfasis que en la época ibérica más arcaica sus ancestros habían hecho en el control de las armas, presentándose sistemáticamente como guerreros armados, responsables de la defensa de sus respectivas comunidades. En un ambiente de gran intensidad bélica como el de finales del s. III a.C., las actitudes militares del gobernante se tornaban ineludibles para la supervivencia de la comunidad, y por lo tanto se convirtieron en un aspecto fundamental en la construcción ideológica del poder. Pero, frente a las representaciones de guerreros armados de la Época Ibérica Arcaica, la iconografía de esta fase tardía presentará una diferencia fundamental: ya no encontraremos solamente combates singulares de aristócratas que se reconocen como iguales, como los de Porcuna o la Alcudia de comienzos del siglo V a.C.; lo que representarán ahora las cerámicas edetanas o las alcoyanas, o el vaso de los Guerreros de Cigarralejo, el de Archena o el de Oliva, todos ellos datables entre finales del s. III y comienzos del II a.C., serán más bien combates entre ejércitos 
relativamente uniformados, o bien desfiles de guerreros que ostentan sus armas, haciendo gala de su condición de grupo armado al servicio de la comunidad. ${ }^{101}$

Se trata de un cambio fundamental en las representaciones sociales, que con toda probabilidad no es sino la culminación de un proceso que había comenzado mucho antes, pues, a diferencia de lo que ocurría en la época más arcaica, en la que solo los grandes potentados de cada comunidad se enterraban con sus armas, en época plena se fue consolidando progresivamente la tendencia a que una parte importante de los varones amortizara elementos de armamento en sus sepulturas, ${ }^{102}$ lo que evidencia que construían su identidad social en torno a su condición de guerreros. Pero, con la escalada bélica de finales del s. III a.C., la importancia de semejante condición se convertirá en el elemento primordial de la autorrepresentación social. La identidad social quedó vinculada a la posesión de las armas hasta un punto que incluso llamó la atención de los autores grecorromanos. ${ }^{103} \mathrm{La}$ influencia del imperialismo cartaginés, en este sentido, se dejaría sentir sobre las estructuras sociopolíticas ibéricas hasta mucho después de la desaparición de aquel, cuando la progresiva integración de todas estas comunidades en las estructuras provinciales romanas y la consiguiente imposición (forzosa en muchos casos) de la pax romana tendería a transformar, una vez más, todos estos discursos ideológicos.

\section{Conclusiones}

En definitiva, si señalaba que el proyecto imperialista bárquida cristalizó en el Sureste peninsular en el establecimiento de una serie limitada de enclaves fortificados que controlaban las vías de comunicación, red que dotaba al estado cartaginés de una posición de fuerza desde la que establecer pactos y tratados (en el fondo, desiguales) con los gobernantes locales, hemos observado que estos pactos, tratados, alianzas e intercambios facilitaron que algunas comunidades ibéricas prosperaran a costa de sus vecinas, convirtiéndose en verdaderos protoestados comarcales, en tanto que otras sencillamente capitalizaron las relaciones con el poder hegemónico en el sureste peninsular, instrumentalizando unos discursos ideológicos crecientemente híbridos que subrayaban y legitimaban su distinción frente a sus súbditos y sus pactos con Cartago.

En todo caso, e independientemente de la plasmación efectiva de estos pactos y de la desigual situación en la que cada comunidad quedó en el cambiante escenario de negociación política, posiblemente una de las consecuencia directas de la presencia del aparato imperialista cartaginés en tierras contestanas, y de la escalada bélica sin precedentes que aquel desató, fuera el rápido proceso de militarización de las diversas comunidades locales, plasmado en la iconografía en unas elites que, a partir de ahora, decidieron representarse como directoras de los grupos armados que cooperaban para la defensa de la comunidad.

Fenómenos todos estos que, desde luego, no resultan comparables a los que la presencia cartaginesa había fomentado en el sureste con anterioridad a la llegada bárquida. Posiblemente porque dicha presencia, aún produciéndose, se circunscribió

García Cardiel 2014c, 162-166.

Quesada 1989, 114-116.

103 Cf., por ejemplo, App. Iber. 31; Flor. 1.34. 
al Campo de Elche y a algunos puertos comerciales aislados, y se plasmó en términos muy distintos a los propios del imperialismo de finales del siglo III a.C., limitándose posiblemente a la existencia de grupos de comerciantes asiduos a los mercados ibéricos. Una presencia que permitió que entre ciertas comunidades del entorno ilicitano los discursos ideológicos (y, por consiguiente, los esquemas iconográficos) se revistieran de un marcado lenguaje "punicizante", pero sin que las estructuras socioeconómicas locales se vieran por fuerza profundamente afectadas.

\section{Referencias bibliográficas}

AA.VV. (1999): Cartagena a través de las colecciones de su Museo Arqueológico, Murcia.

Abad Casal, L. - Sala Sellés, F.

(1997): "Sobre el posible uso cúltico de algunos edificios de la Contestania ibérica", Quaderns de Prehistòria i Arqueologia de Castelló 18, 91-102.

(2001): Poblamiento ibérico en el Bajo Segura. El Oral (II) y La Escuera (=Real Academia de la Historia. Publicaciones del Gabinete de Antigüedades: Bibliotheca Archaeologica Hispana 12), Madrid.

Abad Casal, L. - Sala Sellés, F. - Grau Mira, I. (eds.), (2005): La Contestania Ibérica, treinta años después, Alicante.

Alfaro Giner, C. (2000): “La producción y circulación monetaria en el Sudeste peninsular", [en] M. P. García-Bellido - L. Callegarin (eds.), Los cartagineses y la monetización del Mediterráneo occidental (=Anejos de AEspA 22), Madrid, 101-112.

Almagro Gorbea, M.

(1987): "El área superficial de las poblaciones ibéricas", [en] Los asentamientos ibéricos ante la romanización, Madrid, 21-34.

(1990): “L'Hellénisme dans la culture ibérique", [en] Akten des XIII Internationalen Kongress für Klassische Archäologie 1, Mainz-Rhein, 113-127.

Almagro Gorbea, M. - Ramos Fernández, R. (1986): "El monumento ibérico de Monforte del Cid", Lucentum 5, $45-63$ (http://dx.doi.org/10.14198/LVCENTVM1986.5.03).

Almagro Gorbea, M. - Rubio Gomis, F. (1980): "El monumento ibérico de «Pino Hermoso». Orihuela (Alicante)", Trabajos de Prehistoria 37, 345-362.

Alvar Ezquerra, J. (1986): "Theron, rex Hispaniae Citerioris (Macr., Sat. I, 20, 12)", Gerión 4, 161-175 (http://dx.doi.org/10.5209/GERI.15705).

Álvarez Martí-Aguilar, M.

(2006): "El origen del ariete: Cartago versus Gadir a fines del s. III a.C.", [en] Martínez-Pinna (coord.), 2006, 125-140.

(2009): "Identidad y etnia en Tartesos", Arqueología Espacial 27, 79-111.

(2014): "Hijos de Melqart. Justino (44.5) y la koiné tiria entre los siglos IV y III a.C.", AEspA 87, 21-40 (http://dx.doi.org/10.3989/aespa.087.014.002).

Álvarez-Ossorio, Á. - Ferrer Albelda, E. - García Vargas, E. (coords.), (2014): Piratería y seguridad marítima en el Mediterráneo antiguo (=Spal. Monografías XVII), Sevilla.

Aranegui Gascó, C. (2010): “Ocupación económica, ritual y estratégica del litoral valenciano”, Mainake 32/2, 689-704. 
Arenas Esteban, J. A. (2004): "La influencia del mundo paleopúnico en la Meseta oriental", [en] González Blanco - Matilla - Egea (eds.), 2004, 157-171.

Arribas Palau, A. et alii (1987): El barco de El Sec (Calvià, Mallorca). Estudio de los materiales, Palma de Mallorca.

Aubet Semmler, M. E. (1986): "La necrópolis de Villaricos en el ámbito del mundo púnico peninsular", [en] Homenaje a Luis Siret, Madrid, 612-624.

Barceló Batiste, P. (2006): "Sobre el inicio de la presencia cartaginesa en Hispania", [en] Martínez-Pinna (coord.), 2006, 105-124.

Beltrán Martínez, A.

(1945): "Acerca de los nombres de Cartagena en la Edad Antigua", Archivo de Prehistoria Levantina 2, 301-320.

(1961-1962): "Sobre una extraordinaria moneda de «Saitabi»", [en] Homenaje al profesor Cayetano de Mergelina, Murcia, 153-162.

Bendala Galán, M.

(2003): "De Iberia in Hispaniam: el fenómeno urbano", [en] L. Abad (ed.), De Iberia in Hispaniam. La adaptación de las sociedades ibéricas a los modelos romanos, Alicante, 15-35.

(2005): "La Contestania ibérica y el mundo púnico", [en] Abad - Sala - Grau (eds.), 2005, 37-51.

(2013): “Aníbal y los Barca: el proyecto político cartaginés de Hispania”, [en] M. Bendala (ed.), Fragor Hannibalis. Anibal en Hispania, Madrid, 46-81.

(2015): Hijos del Rayo. Los Barca y el dominio cartaginés en Hispania, Madrid.

Bhabha, H. J. (1994): The location of culture, London.

Bilde, P. et alii (1996): Aspects of Hellenistic kingship (=Studies in Hellenistic Civilization 7), Aarshus.

Blánquez Pérez, J. J.

(1996): "Lugares de culto en el mundo ibérico. Nuevas propuestas interpretativas de espacios singulares en el sureste meseteño", Revista de Estudios Ibéricos 2, 147-172. (2004): "La ciudad de Carteia (San Roque, Cádiz) en época púnica", [en] González Blanco -Matilla - Egea (eds.), 2004, 137-156.

Blázquez Martínez, J. M. (1988): "El urbanismo en Occidente”, [en] Homenaje a Samuel de los Santos, Murcia, 179-183.

Blázquez Martínez, J. M. - García-Gelabert, M. P. (1991): “Los bárquidas en la Península Ibérica", [en] II Congresso Internazionale di Studi Fenici e Punici 1, Roma, 27-50.

Broncano Rodríguez, S. (1989): El depósito votivo ibérico de El Amarejo. Bonete (Albacete), (=Excavaciones Arqueológicas en España 156), Madrid.

Chapa Brunet, T. - Belén Deamos, M. (2011): "Viaje a la eternidad. El grupo escultórico del Parque Infantil de Tráfico (Elche, Alicante)", Spal 20, 151-174 (http://dx.doi.org/10.12795/spal.2011.i20.10).

Chic García, G. (1978): "La actuación político-militar cartaginesa en la Península Ibérica entre los años 237 y 218", Habis 9, 233-242.

Demargne, P. (1958): Fouilles de Xanthos I. Les piliers funéraires, Paris.

Dietler, M. (2010): Archaeologies of colonialism. Consumption, Entanglement and Violence in Ancient Mediterranean France, Berkeley-Los Angeles-London.

Ferrer Albelda, E.

(1996a): La España cartaginesa: claves historiográficas para la historia de España, Sevilla. 
(1996b): "Los púnicos de Iberia y la historiografía grecolatina", Spal 5, 115-131 (http://dx.doi.org/10.12795/spal.1996.i5.06).

(2002-2003): "Gloria y ruina de la Iberia Cartaginesa. Imágenes del poder en la historiografía española", CuPAUAM 28-29, 7-21 (http://dx.doi.org/10.15366/ cupauam2003.29.001).

(2006): “'Mastia en África?”, [en] A. Akerraz et alii (eds.), L'Africa Romana, Roma, 1997-2008.

(2009): "A propósito de Tagilit y de otras ciudades púnicas del sureste de Iberia", [en] R. Cruz-Auñón - E. Ferrer (coords.), Estudios de prehistoria y arqueología en homenaje a Pilar Acosta Martínez, Sevilla, 407-418.

(2011a): "Más acá y más allá de las Columnas de Heracles. Mastia Tarseion y las limitaciones al comercio en Iberia", CuPAUAM 37-38, 431-445 (http://dx.doi. org/10.15366/cupauam2012.38.021).

(2011b): "Rasgos ideológicos helenísticos en la política ibérica de los Barca", [en] J. M. Cortés - E. Muñiz - R. Gordillo (coords.), Grecia ante los Imperios (=Spal. Monografías 15), Sevilla, 305-316.

Ferrer Albelda, E. - De La Bandera Romero, M. L. (1997): "La localización de Mastia: un aspecto problemático de los conocimientos geográficos griegos sobre Iberia", [en] F. J. Presedo et alii (eds.), Xaire. II reunión de historiadores del mundo antiguo. Homenaje al profesor Fernando Gascó, Sevilla, 65-72.

Ferrer Albelda, E. - Pliego Vázquez, R. (2010): “... Auxilium consanguineis Karthaginiensis misere: un nuevo marco interpretativo de las relaciones entre Cartago y las comunidades púnicas de Iberia", Mainake 32/1, 525-557.

Figueras Pacheco, F. (1952): "Los cartagineses en el iberismo del Sudeste", [en] II Congreso Nacional de Arqueología, Zaragoza, 421-433.

Frutos Reyes, G. (1991): Cartago y la política colonial. Los casos norteafricano e hispano, Écija.

García-Bellido, M. P. (2010): “¿Estuvo Ákra Leuké en Carmona?”, [en] Serta Palaeohispanica in honorem Javier de Hoz (=Palaeohispanica 10), Zaragoza, 201-218.

García Cardiel, J.

(2013): El catálogo de las naves de Occidente. Embarcaciones de la Península Ibérica, Marruecos y archipiélagos aledaños hasta el principado de Augusto (=BAR International Series 2462), Oxford.

(2014a): "Lenguajes híbridos y reestructuración política en las áreas sacras de la Contestania central durante el s. III a.C.", Dialogues d'Histoire Ancienne 40/2, 111-136.

(2014b): “¿Rasgos púnicos en los santuarios ibéricos? Religión e identidad en la Contestania central", Saguntum 46, 79-91 (http://dx.doi.org/10.7203/SAGVNTVM.46.3270).

(2014c): "El combate contra el Mal: imaginarios locales de poder a través de la conquista romana en el Levante ibérico", Complutum 25/1, 159-175 (http:// dx.doi.org/10.5209/rev_CMPL.2014.v25.n1.45361).

(2015): "Pebeteros en la costa. Santuarios, peregrinaciones y rituales en la Contestania ibérica (ss. III-II a.C.)", Zephyrus 76, 77-98 (http://dx.doi.org/10.14201/ zephyrus2015767798).

(2016): Los discursos del poder en el mundo ibérico del Sureste (siglos VII-I a.C.), (=CSIC. Bibliotheca Praehistorica Hispana 31), Madrid. 
García León, J. et alii (2017): "Paleotopographical virtual reconstruction of the historic city of Cartagena (Spain)", Virtual Archaeology Review 8/16, 61-68 (http:// dx.doi.org/10.4995/var.2017.5836).

García Menárguez, A. - Prados Martínez, F. (2017): “Las defensas y la trama urbana del Cabezo del Estaño de Guardamar. Un encuentro fortificado entre fenicios y nativos en la desembocadura del río Segura (Alicante)", [en] F. Prados - F. Sala (eds.), El Oriente de Occidente. Fenicios y púnicos en el área ibérica, Alicante, 51-78.

González Blanco, A. - Matilla, G. - Egea, A. (eds.), (2004): El mundo púnico. Religión, antropología y cultura material (=Universidad de Murcia. Instituto del Próximo Oriente Antiguo. Estudios orientales 5-6), Murcia, 2004.

González Prats, A. (2010): "La presencia fenicia en el Bajo Segura", [en] Guardamar del Segura, arqueología y museo, Alicante, 58-65.

González Wagner, C.

(1983): Fenicios y cartagineses en la Península Ibérica: ensayo de interpretación fundamentado en un análisis de los factores internos, Madrid.

(1999): "Los bárquidas y la conquista de la Península Ibérica”, Gerión 17, 263 294 (http://dx.doi.org/10.5209/GERI.15235).

Grau Mira, I. - Amorós López, I. (2017): "Los primeros tiempos del santuario ibérico: identidad y poder en la ciudad del s. III a.C.", [en] I. Grau - I. Amorós - J. M. Segura (eds.), El santuario ibérico y romano de La Serreta (Alcoi, Cocentaina, Penàguila). Prácticas rituales y paisaje en el área central de la Contestania, Alcoy, 131-159.

Koch, M. (2001): "Cartago e Hispania anteriores a los Bárquidas”, [en] F. Villar-M. P. Fernández Álvarez (eds.), Religión, lengua y cultura prerromanas de Hispania (=Universidad de Salamanca. Acta Salmanticensia. Estudios Filológicos 283), Salamanca, 189-197.

Lafuente Vidal, J.

(1934): Excavaciones en la Albufera de Alicante, Madrid.

(1952): "Influencia de los cultos religiosos cartagineses en los motivos artísticos de los iberos del S.E. español", Archivo de Prehistoria Levantina 3, 159-177.

Llobregat Conesa, E. A.

(1969): "Hacia una desmitificación de la Historia Antigua de Alicante. Nuevas perspectivas sobre algunos problemas", Revista del Instituto de Estudios Alicantinos 1, 35-55.

(1981): "Revisión del papel de los cartagineses en la Historia Antigua del País Valenciano", [en] I Congreso de Historia del País Valenciano 2, Valencia, 283-290.

(1985): "Dos temples ibèrics a l'interior del poblat de l'Illeta dels Banyets", Fonaments 5, 103-111.

(1994): “Tradición religiosa fenicio-púnica en Contestania", [en] A. González Blanco - J. L. Cunchillos - M. Molina (coords.), El mundo púnico. Historia, sociedad y cultura (=Biblioteca básica murciana. Extra 4), Murcia, 169-175.

Llorens Forcada, M. M. (1993): La ciudad de Carthago Nova: las emisiones romanas (=La ciudad romana de Carthago Nova, fuentes y materiales para su estudio 6), Murcia.

López Castro, J. L. (1991): “El imperialismo cartaginés y las ciudades fenicias de la Península Ibérica entre los siglos VI-III a.C.", Studi di Egittologia e di Antichità Puniche 9, 87-107. 
López Pardo, F. - Suárez Padilla, J. (2002): “Traslados de población entre el norte de África y el sur de la Península Ibérica en los contextos coloniales fenicio y púnico", Gerión 20/1, 113-152 (http://dx.doi.org/10.5209/GERI.15133).

Lucas Pellicer, M. R. (2001-2002): "Entre dioses y hombres: el paradigma de «El Cigarralejo» (Mula, Murcia)", Anales de Prehistoria y Arqueología de Murcia 16-17, 147-158.

Marín Baño, C. (1997-1998): “Un modelo estratigráfico de la Cartagena púnica: la muralla de Quart-Hadast", Anales de Prehistoria y Arqueología de Murcia 13-14, 121-139.

Marín Ceballos, M. C. - Belén Deamos, M. - Jiménez Florez, A. M. (2010): “El proyecto de estudio de los materiales de la cueva de Es Culleram", Mainake 32/1, 133-157.

Martín Camino, M. - Roldán Bernal, B. (1991-1992): “Nota sobre el comercio marítimo en Cartagena durante época púnica a través de algunos hallazgos subacuáticos", Anales de Prehistoria y Arqueología de Murcia 7-8, 151-162.

Martínez-Pinna, J. (coord.), (2006): Initia rerum. Sobre el concepto del origen en el mundo antiguo (=Universidad de Málaga. Thema 49), Málaga.

Moratalla Jávega, J.

(2004-2005): "La Alcudia ibérica: una necesaria reflexión arqueológica", Lucentum 23-24, 89-104.

(2005): "El territorio meridional de la Contestania", [en] Abad - Sala - Grau (eds.), 2005, 91-117.

Moret, P. (2002): “Mastia tarseion y el problema geográfico del segundo tratado entre Cartago y Roma", Mainake 24, 257-276.

Nordström, S. (1961): Los cartagineses en la costa alicantina, Alicante.

Olcina Domenech, M. H.

(1997): “Excavacions al poblat i necrópolis de la Serreta. Any 1997”, Recerques del Museu d'Alcoi 6, 165-173.

(2005): "La Illeta dels Banyets, el Tossal de Manises y La Serreta", [en] Abad Sala - Grau (eds.), 2005, 147-177.

Olcina Domenech, M. H. - Grau Mira, I. - Moltó Gisbert, S. (2000): “El sector I de La Serreta: noves perspectives sobre l'ocupació de l'assentament", Recerques del Museu d'Alcoi 9, 119-144.

Olcina Domenech, M. H. - Grau Mira, I. - Sala Sellés, F. - Moltó Gisbert, S. - Segura Martí, J. M. - Reig Seguí, C. (1998): "Nuevas aportaciones a la evolución de la ciudad ibérica: el ejemplo de La Serreta", [en] C. Aranegui (coord.), Los iberos, príncipes de Occidente. Estructuras de poder en la sociedad ibérica (Saguntum. Extra 1), Valencia, 35-46.

Olcina Domenech, M. H. - Guilabert Mas, A. - Tendero Porras, E. (2010): "Lectura púnica del Tossal de Manises (Alicante)", Mainake 32/1, 229-249.

Olcina Domenech, M. H. - Martínez Sala, A. - Sala Sellés, F. (2009): La Illeta dels Banyets (El Campello, Alicante). Épocas ibérica y romana I. Historia de la investigación y síntesis de las intervenciones recientes (2000-2003), (=Museo Arqueológico Provincial de Alicante. Serie Mayor 7), Alicante.

Olmos Romera, R. (dir.), (1992): La sociedad ibérica a través de la imagen, Madrid. Pérez Ballester, J. (1995): "La actividad comercial y el registro arqueológico en la Carthago Nova republicana. Los hallazgos del área del anfiteatro", Verdolay 7, 339-349. 
Pérez Vilatela, L. (2003): "Polibio (III, 33, 9s.) y la administración territorial cartaginesa de Iberia", Hispania Antiqua 27, 7-42.

Pliego Vázquez, R. (2003): "Sobre el reclutamiento de mercenarios turdetanos. El campamento cartaginés de El Gandul (Alcalá de Guadaira, Sevilla)", Habis 34, $39-56$.

Poveda Navarro, A. M. - Vázquez Hoys, A. M. (2000): "Incidencia púnica y oriental en el panorama religioso autóctono del sureste de la Península Ibérica", [en] M. E. Aubet - M. Barthélemy (eds.), IV Congreso Internacional de Estudios Fenicios y Púnicos 2, Cádiz, 697-708.

Prados Martínez, F. (2002-2003): "Memoria del poder. Los monumentos funerarios ibéricos en el contexto de la arquitectura púnico-helenística", CuPAUAM 28-29, 203-226 (http://dx.doi.org/10.15366/cupauam2003.29.010).

Quesada Sanz, F. (1989): “Consideraciones sobre el uso del armamento ibérico para la delimitación de unidades geopolíticas”, Arqueología Espacial 13, 111-120.

Ramos Fernández, R. (1995): El templo ibérico de La Alcudia. La Dama de Elche, Elche.

Ramos Fernández, R. - Ramos Molina, A. (1992): El monumento y témenos ibéricos del Parque de Elche (=Serie Gran 2), Elche.

Ramos Folqués, A. (1968): "El nivel ibero-púnico de la Alcudia de Elche (Alicante)", Rivista di Estudi Liguri 34, 363-386.

Rueda Galán, C. - Olmos Romera, R. (2010): "Un exvoto ibérico con los atributos de Heracles: la memoria heroica en los santuarios", [en] T. Tortosa - S. Celestino (eds), Debate en torno a la religiosidad protohistórica (=Anejos de AEspA 55), Madrid, 37-48.

Sala Sellés, F. (2001-2002): "Para una revisión de las relaciones púnicas con la costa ibérica alicantina: nuevas perspectivas sobre algunos viejos problemas", Anales de la Universidad de Murcia 16-17, 283-300.

(2010): "Nuevas perspectivas sobre las relaciones púnicas con la costa ibérica del Sureste peninsular", Mainake 32/2, 933-950.

Uroz Rodríguez, H. (2006): El programa iconográfico religioso de la "Tumba del Orfebre" de Cabezo Lucero (Guardamar del Segura, Alicante), (=Monografías del Museo de Arte Ibérico de El Cigarralejo 3), Murcia.

Verdú Parra, E. (2014): La necrópolis ibérica de L'Albufereta. Ritos y usos funerarios en un contexto de interacción cultural (=Museo Arqueològico Provincial de Alicante. Serie Mayor 11), Alicante. 